\title{
MINERALOGICAL INVESTIGATION AND PRELIMINARY BENEFICIATION TESTS FOR UPGRADING THE HUDENISHT NICKELIFEROUS LATERITIC ORE
}

\author{
G. Alevizos ${ }^{1}$, A. Stratakis ${ }^{1 \#}$, E. Petrakis ${ }^{1}$, R. Tselempis ${ }^{1}$, A. Apostolikas ${ }^{2}$ \\ ${ }^{1}$ Technical University of Crete, School of Mineral Resources Engineering, Chania, Greece \\ ${ }^{2}$ Larco GMMSA, Athens, Greece
}

(Received: June 14, 2018; Accepted: September 28, 2018)

\begin{abstract}
The nickeliferous iron ore of Hudenisht is located in the Pogradec area, Albania. It is developed in layers above altered ophiolite and is covered by limestone of the Upper Cretaceous. The ore was characterized through XRD, ore microscopy and SEM analysis and found that the main mineral phases are hematite, goethite and chromite, with chlorite (clinochlore, nimite), lizardite, calcite and spinel as minor phases. The main Ni-bearing phase is nimite, which appears mainly in the groundmass of the ore. The chemical analysis through XRF showed that it is a lowgrade nickel ore (about $0.8 \% \mathrm{NiO}$ ) with $\mathrm{Fe}_{2} \mathrm{O}_{3}(74 \%)$ as the most abundant constituent. The ore was upgraded through physical beneficiation processes, namely gravimetric and magnetic separations. The received samples were homogenized, crushed to $-8 \mathrm{~mm}$ and the product was sieved following the wet sieving procedure to obtain four size fractions, i.e. $-8+4 \mathrm{~mm},-4+1 \mathrm{~mm},-1+0.250 \mathrm{~mm}$ and $-0.250+0.063 \mathrm{~mm}$. Each fraction was subjected to upgrading and the chemical analysis through XRF showed that the best results among the two processes were obtained through the gravimetric separation. It is observed that the float products are richer in nickel mainly in finer size fractions.
\end{abstract}

Key words: nickeliferous lateritic ore; beneficiation process; magnetic separation; gravimetric separation; ore microscopy; Hudenisht.

\section{Introduction}

Although nickel is one of the common metals in the earth, the exploitable nickel deposits are more restricted and it is believed that these deposits will last for another 100 years. Nickel is mainly used as an alloying agent since it improves their properties, e.g. high strength and toughness, excellent corrosion resistance, higher temperature properties. Additions of other metals, such as gold and chromium lead to the production of alloys with a wide range of applications. About $66 \%$ of the primary nickel consumption is dominated by stainless steel. Non-ferrous alloys account for $12 \%$, followed by alloy steel which accounts for 5\% [1].

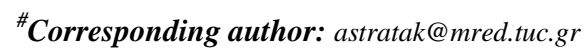

doi: 10.5937/JMMA1801035A
The nickeliferous ores can be divided into two categories, namely sulfide ores and laterites. Although nickel laterites constitute about $70 \%$ of the global reserves, they represent only $45 \%$ of $\mathrm{Ni}$ production [2]. In the past, Ni production was mainly dependent on the treatment of higher $\mathrm{Ni}$ grade sulfide ores because they are easier to exploit and process. However, due to the reduction of sulfide ore reserves, the focus gradually shifted to low-grade nickel lateritic ores $[3,4$, $5,6,7]$.

The Hudenisht lateritic ore is characterized as secondary pseudoautochthonous deposit [8]. The Balkan deposits (Greece, Albania and former Yugoslavia) are "fossil" deposits, currently 
situated in temperate or arid climates, quite different from the warm, humid conditions, under which they are formed [9].

Many processes have been developed for the treatment of laterite ores. These involve pyrometallurgical and hydrometallurgical techniques or physical beneficiation processes $[10,11,12]$. Low-grade laterites cannot be economically treated pyrometallurgically as it is an energy-intensive technique and therefore alternative, less expensive technologies should be developed [13]. This study attempts to upgrade the Hudenisht lateritic ore through gravimetric and magnetic separation processes. If it is successfully upgraded, the ore can be used for further treatment, e.g. froth flotation, which will be examined in the future.

\section{Geology}

From a geological point of view, Albania is part of the alpine system, which extends from the Dinarides in the east through to the internal Hellinides in the south. The geological structure of the Albanides comprises of two major units, namely the Internal Albanides to the east and the External Albanides to the west [14]. The Mirdita geotectonic zone crosses Albania from north to south, belongs to the Internal Albanides and is associated with ophiolitic complexes of Jurassic age. The Mirdita zone is also subdivided into two ophiolitic zones with different tectonic origin, i.e. the Eastern zone and Western zone. Hartzburgites is found in both of these zones, mainly in the Eastern one, while in the Western zone there are mainly lherzolites [15]. In North and Central Albania the ferruginization evolved before or during Lower Cretaceous and in the South before Eocene. The nickel ferruginization in the central-east of the country occurs in the area of Pogradec, where the Hudenisht deposit belongs [4].

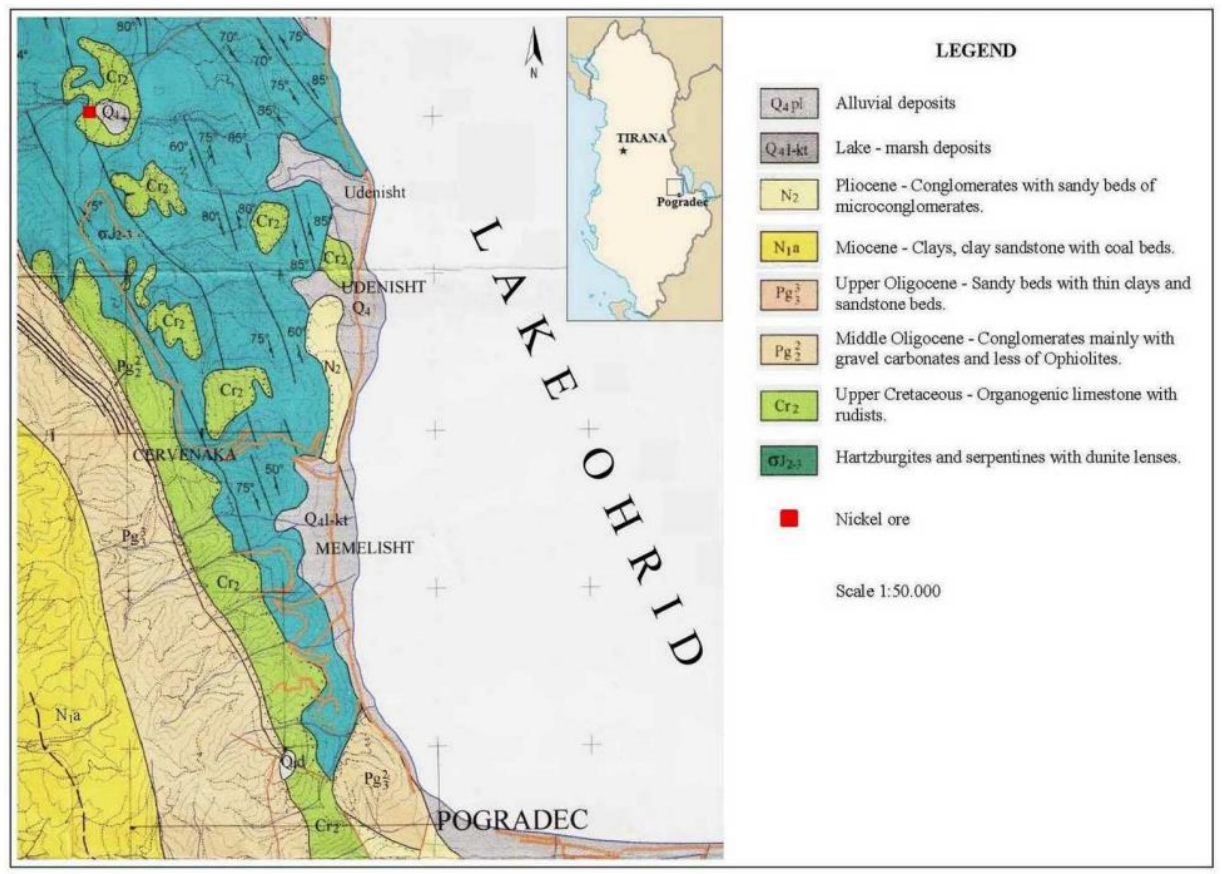

Figure 1. Modified geological map of Hudenisht (Pogradec, Albania) 
The Hudenisht deposit is located $12 \mathrm{~km}$ north of Pogradec, northwest of the Ohrid Lake (Figure 1). The iron-nickel ore occurs in the form of layers with a total thickness of 8.5 $\mathrm{m}$ between ultramafic rocks of varying composition (from hartzburgites to serpentinites). The ore is covered by limestone of the Upper Cretaceous [8]. The ferruginized area is subdivided into two areas. The eastern area is characterized by the ophiolitic complex Pogradec-Librazhd, with a length of $50 \mathrm{~km}$ and is associated with deposits overlying ultramafic rocks; the first deposits that have been exploited. These rocks are lateritic weathering crusts overlaid by hartzburgites-serpentinites and covered by limestones of the Upper Cretaceous. The most important deposits from north to south are the following: Bushtrica, Skroska, Prrenjas, Hudenisht, Cervenaka and Guri I Kuq. The ferruginized layers measure up to $1.5 \mathrm{~km}$ in length and 2-25 $\mathrm{m}$ in width. The total amount of nickeliferous ore is estimated to $105 \times 10^{6}$ tonnes with average nickel and cobalt contents of $0.98 \%$ and $0.07 \%$, respectively [4].

\section{Experimental procedure}

The mineralogical examination of the nickeliferous ore was carried out using the $\mathrm{X}$ ray diffraction method (XRD). The automated X-ray diffractometer, D8 Advance of BrukerAXS Company was used. The identification of the ore minerals, the description of the fabric and the examination of the intergrowth in the different products were performed with an ore microscopy. A JENA ore microscope equipped with an OLYMPUS digital camera was used. The mineralogical characteristics of the ore samples have been investigated by using a scanning electron microscope (SEM) Jeol model JSM5400 in conjunction with EDSmicroanalysis. The chemical analysis of nickeliferous ore was carried out using the automated X-ray fluorescence spectrometer (XRF), S2 Ranger of BrukerAXS Company.

The beneficiation procedure was performed using gravimetric and magnetic separation. The received samples (approx. $60 \mathrm{~kg}$ ) were homogenized by the cone and quarter method and a representative material of $2.5 \mathrm{~kg}$ was used for the tests. The material was crushed with the use of a jaw crusher to a size of $-8 \mathrm{~mm}$ and the product was wet sieved to obtain four size fractions $(-8+4 \mathrm{~mm},-4+1$ $\mathrm{mm},-1+0.250 \mathrm{~mm}$ and $-0.250+0.063 \mathrm{~mm}$ ).

The gravimetric separation of the size fractions $-8+4 \mathrm{~mm},-4+1 \mathrm{~mm},-1+0.250 \mathrm{~mm}$ and $-0.250+0.063 \mathrm{~mm}$ was carried out using tetrabromoethane $\left(\mathrm{d}=2.96 \mathrm{~g} / \mathrm{cm}^{3}\right)$ as the heavy liquid. Furthermore, additional experiments were conducted using heavy liquids in the form of suspension which is a common practice in the industry. In this respect, a higher medium density was obtained $(\mathrm{d}=4$ $\mathrm{g} / \mathrm{cm}^{3}$ ) by placing $600 \mathrm{~g}$ of finely divided ferro-silicon $(\mathrm{FeSi})\left(\mathrm{d}=7.2 \mathrm{~g} / \mathrm{cm}^{3}\right)$ in $300 \mathrm{ml}$ bromoform $\left(\mathrm{CHBr}_{3}\right)$. The heavy suspension liquid technique is generally sufficient for the separation of coarse particles, which is not particularly sensitive to fluctuations in the viscosity of the heavy liquid. However, this technique is not suitable for separation of fine particles and therefore only the coarse fractions $-8+4 \mathrm{~mm}$ and $-4+1 \mathrm{~mm}$ were used. The gravimetric separation enables separation between lighter mineral phases, i.e. quartz $\left(\mathrm{d}=2.65 \mathrm{~g} / \mathrm{cm}^{3}\right)$, calcite $\left(2.6-2.8 \mathrm{~g} / \mathrm{cm}^{3}\right)$, lizardite $\left(2.5-2.7 \mathrm{~g} / \mathrm{cm}^{3}\right)$, chlorite (2.6-3.3 $\mathrm{g} / \mathrm{cm}^{3}$ ) and heavier minerals, i.e. hematite $\left(\mathrm{d}=5.26 \mathrm{~g} / \mathrm{cm}^{3}\right)$, goethite $\left(3.3-4.3 \mathrm{~g} / \mathrm{cm}^{3}\right)$, chromite $\left(4.2-5.1 \mathrm{~g} / \mathrm{cm}^{3}\right)$.

As far as the magnetic separation is concerned, a high intensity Perm Roll belt separator with magnetic field strength of $0.5 \mathrm{~T}$ was used for the size fractions $-8+4 \mathrm{~mm}$ and $-4+1 \mathrm{~mm}$. 
According to the procedure, each size fraction was separated in three passes with increasing rotation frequency, starting with a rotation frequency of $180 \mathrm{rpm}$. Then, the magnetic product was passed at $220 \mathrm{rpm}$ and finally at $260 \mathrm{rpm}$. In each pass, the nonmagnetic product is collected while the magnetic product is used to feed the next pass. Finally, the three non-magnetic products and the magnetic one were collected, weighed and chemically analyzed. For the fractions $-1+0.250 \mathrm{~mm}$ and $-0.250+0.063 \mathrm{~mm} \mathrm{a}$ laboratory Induced Roll electromagnetic separator MIH 111-5 by Carpco was used. The electric current was set to the highest value, i.e. $\mathrm{I}=3 \mathrm{~A}$ (magnetic field strength of $1.1 \mathrm{~T}$ ), and the same procedure described previously was followed.

\section{Mineralogy}

The mineralogical investigation was performed to nine representative samples (P1P9) of the lateritic nickeliferous ore deposit (Figure 2). The geological profile of the deposit mainly consists of the ophiolite sequence at the base with a clay $\mathrm{Fe}-\mathrm{Ni}$ layer above it. After that, there is a series of $\mathrm{Fe}-\mathrm{Ni}$ pisolitic layers and compact $\mathrm{Fe}-\mathrm{Ni}$ layer with few pisolites, which finally comes to a transitional zone in the top underlying the limestone roof (cup rock).

The main mineral phases, which have been primarily identified by the microscopic examination and the $\mathrm{X}$-ray diffraction analysis are hematite $\mathrm{Fe}_{2} \mathrm{O}_{3}$, goethite $\mathrm{FeOOH}$, chromite $(\mathrm{Fe}, \mathrm{Mg})(\mathrm{Al}, \mathrm{Cr})_{2} \mathrm{O}_{4}$, while in minor quantities chlorite [clinochlore $(\mathrm{Mg}, \mathrm{Fe}, \mathrm{Al})_{6}$ $(\mathrm{Si}, \mathrm{Al})_{4} \mathrm{O}_{10}(\mathrm{OH})_{8}$, nimite $(\mathrm{Ni}, \mathrm{Mg}, \mathrm{Al})_{6}(\mathrm{Si}, \mathrm{Al})_{4}$ $\left.\mathrm{O}_{10}(\mathrm{OH})_{8}\right]$, lizardite $(\mathrm{Mg}, \mathrm{Fe})_{3} \mathrm{Si}_{2} \mathrm{O}_{5}(\mathrm{OH})_{4}$, calcite $\mathrm{CaCO}_{3}$ and spinel $(\mathrm{Mg}, \mathrm{Ni})(\mathrm{Al}, \mathrm{Fe})_{2} \mathrm{O}_{4}$ are also present.

The sample from the altered ophiolite, which is the underlying rock, is too friable and the X-ray diffraction analysis has shown mainly the presence of lizardite, goethite, hematite, chromite and nimite. The $\mathrm{X}$-ray fluorescence method showed the highest $\mathrm{NiO}$ content $(2.81 \%)$ in this layer.

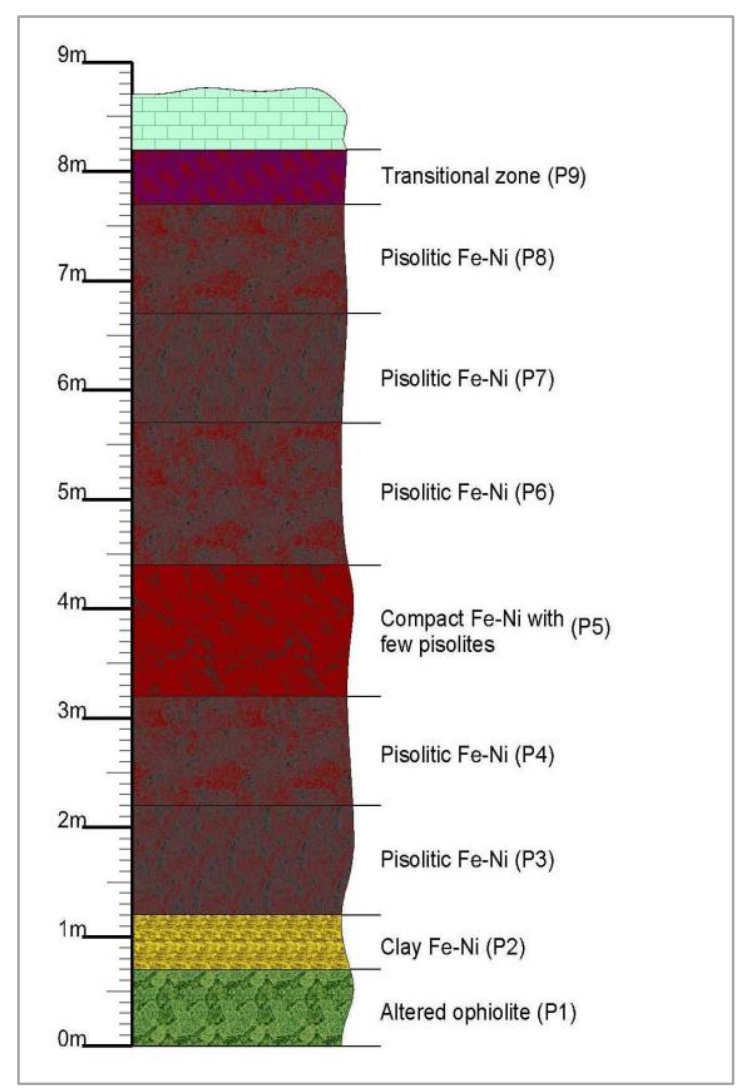

Figure 2. Geological profile of the nickeliferous deposit of Hudenisht (Pogradec, Albania)

Accordingly, high $\mathrm{NiO}$ content is also observed in the clay iron nickel layer (1.77\%). In this layer, individual grains of chromite were observed to be scattered in the clay binder, while nickel chlorite (nimite) was indicated by XRD (Figure 3). Nickel chlorite (nimite) is also observed in the nickel lateritic ore of Nome (Albania), with $\mathrm{NiO}$ concentration between 2.63 to $3.62 \%$ [16]. The groundmass is gradually replaced by ferrous solutions in the form of goethite, which alters to hematite due to dehydration. 


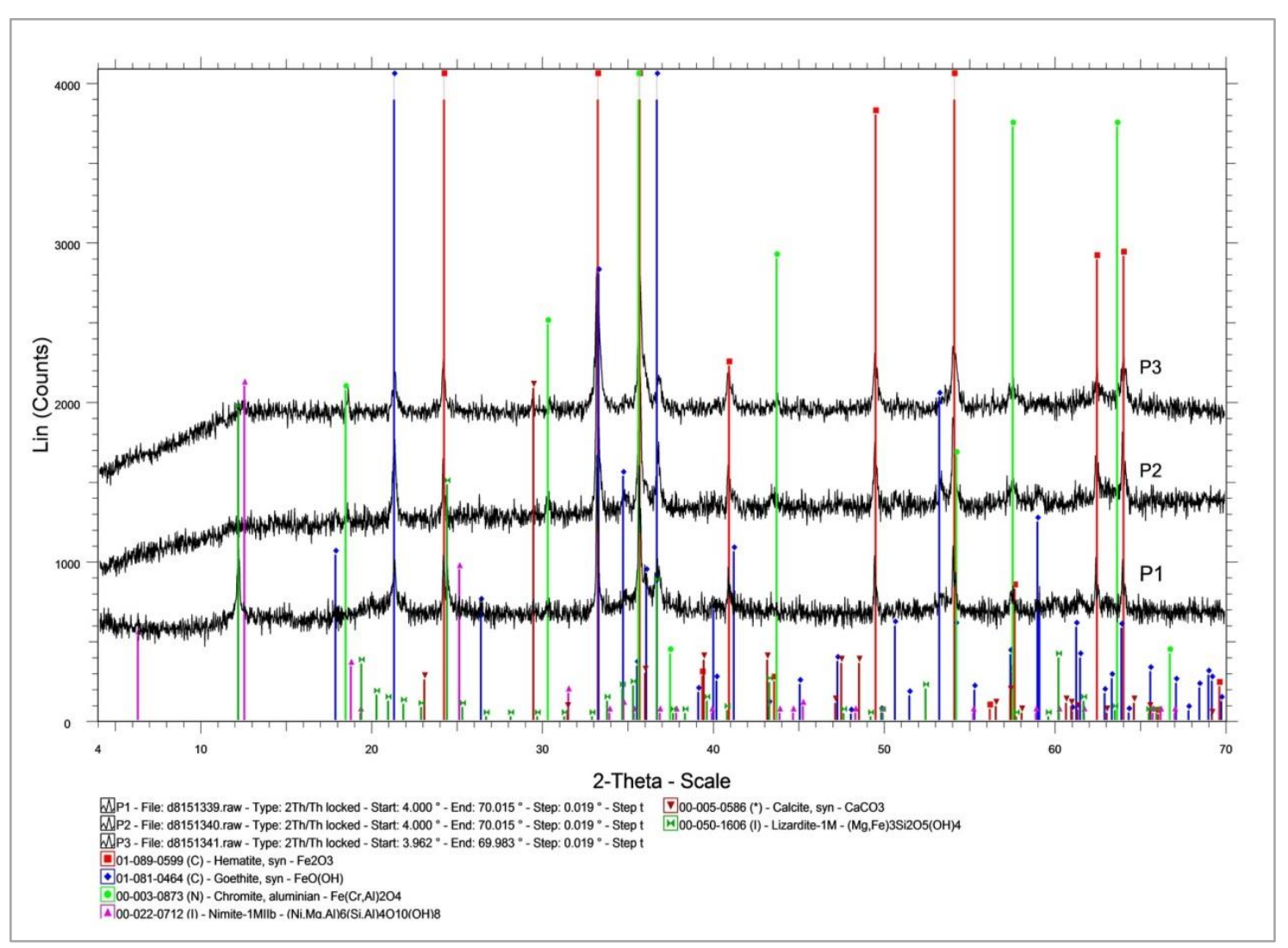

Figure 3. X-ray diffraction patterns of the samples P1, P2 and P3

Thereafter, a series of pisolitic $\mathrm{Fe}-\mathrm{Ni}$ layers follow with a thickness of about $7 \mathrm{~m}$. Spheroid particles of various sizes were identified in these layers. A large number of ooids with concentric shells consisting of hematite and goethite are also observed. The peloids are also widespread in all layers of pisolitic ore in the form of hematite as a dehydration product of goethite. Complex spheroids were also found in all layers of the ore, having integrated preexisting ooids, peloids as well as grains of chromite and spinels (intergranular texture). Many clastic dispersed grains of chromite were observed in the groundmass of the ore (Figure 4). Fragmentation of the crystals is also observed due to tectonic stress (cataclastic texture) [17].

In the upper, transitional zone, a small number of ooids, peloids and complex spheroids is observed with high content of $\mathrm{CaO}(26.47 \%)$ which exists in the form of calcite.This zone transits gradually to a limestone roof.

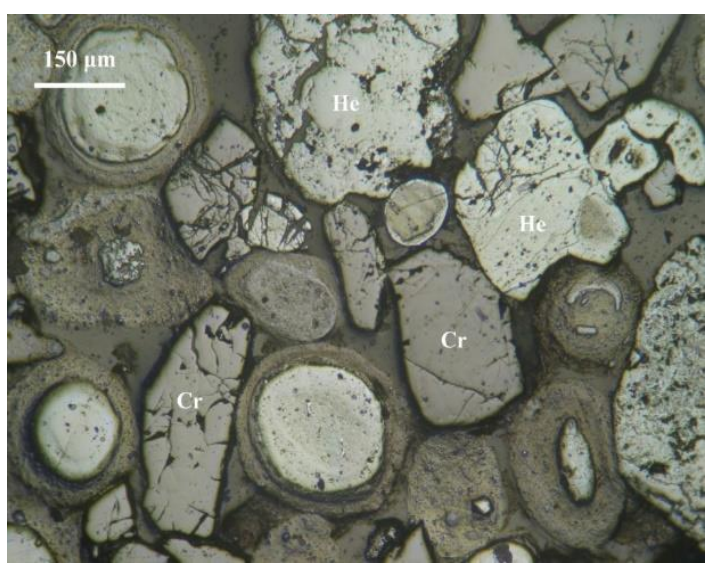

Figure 4. Clastic grains of hematite (He) and chromite (Cr). Reflected light, // Nicols 

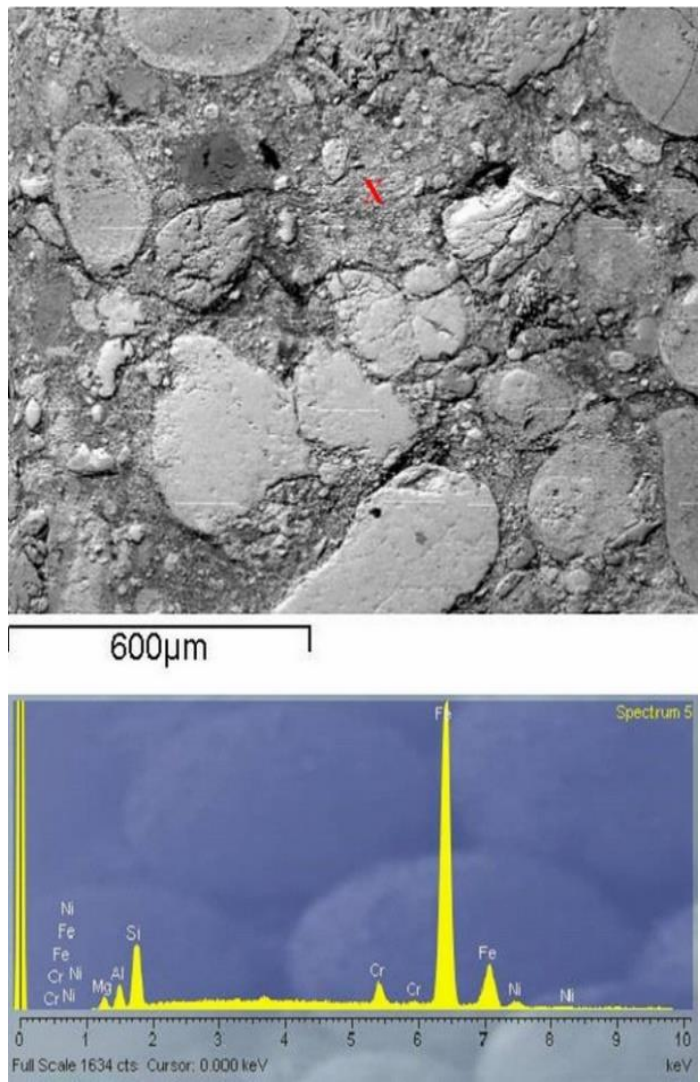

Figure 5. A SEM image and EDS-analysis of clay-groundmass, submitted to replacement by ferrous solutions

The groundmass of the ore consists of clay minerals. Chlorite in the groundmass is the main nickel mineral of the ore. The clay ore material is gradually replaced by ferrous solutions of epigenetic origin, in the form of goethite, which alters to hematite due to dehydration, as already mentioned (Figure 5).

The ore is generally characterized by an allotriomorphic inequigranular structure and an oolithic-pisolitic texture. The presence of ooids, peloids, complex spheroids, as well as the clastic grains of chromite in $\mathrm{Fe}-\mathrm{Ni}$-ores support the view that allochthonous pisolitic material was transported and redepositioned onto ultrabasic rocks. According to the fabric, the nickel lateritic ore of Hudenisht is described as secondary pseudo-autochthonous deposit, overlying a typical autochthonous laterite horizon [8].

The chemical analyses of representative samples collected from various parts of the nickeliferous ore deposit are presented in Table 1.

Table 1. Chemical composition (wt $\%$ ) of representative samples from various parts

of the deposit profile

\begin{tabular}{|l|c|c|c|c|c|c|c|c|c|c|c|c|}
\hline Sample & $\begin{array}{c}\mathbf{S i O}_{\mathbf{2}} \\
(\boldsymbol{\%})\end{array}$ & $\begin{array}{c}\mathbf{A l}_{\mathbf{2}} \mathbf{O}_{\mathbf{3}} \\
(\boldsymbol{\%})\end{array}$ & $\begin{array}{c}\mathbf{C r}_{\mathbf{2}} \mathbf{O}_{\mathbf{3}} \\
(\boldsymbol{\%})\end{array}$ & $\begin{array}{c}\mathbf{F e}_{\mathbf{2}} \mathbf{O}_{\mathbf{3}} \\
(\boldsymbol{\%})\end{array}$ & $\begin{array}{c}\mathbf{M n O} \\
(\boldsymbol{\%})\end{array}$ & $\begin{array}{c}\mathbf{M g O} \\
(\boldsymbol{\%})\end{array}$ & $\begin{array}{c}\mathbf{C a O} \\
(\boldsymbol{\%})\end{array}$ & $\begin{array}{c}\mathbf{K}_{\mathbf{2}} \mathbf{O} \\
(\boldsymbol{\%})\end{array}$ & $\begin{array}{c}\mathbf{N i O} \\
(\boldsymbol{\%})\end{array}$ & $\begin{array}{c}\mathbf{C o O} \\
(\boldsymbol{\%})\end{array}$ & $\begin{array}{c}\mathbf{L O I} \\
(\boldsymbol{\%})\end{array}$ & $\begin{array}{c}\mathbf{S U M} \\
(\boldsymbol{\%})\end{array}$ \\
\hline P1 & 15.60 & 2.26 & 0.71 & 56.72 & 0.79 & 6.98 & 0.71 & 0.01 & 2.81 & 0.16 & 13.29 & 100.02 \\
\hline P2 & 5.34 & 2.30 & 5.20 & 73.10 & 0.19 & 2.22 & 0.76 & 0.01 & 1.77 & 0.24 & 8.74 & 99.88 \\
\hline P3 & 5.32 & 3.88 & 8.69 & 72.27 & 0.25 & 2.09 & 0.89 & 0.01 & 0.84 & 0.16 & 5.47 & 99.86 \\
\hline P4 & 5.97 & 4.41 & 4.09 & 76.13 & 0.21 & 2.62 & 0.85 & 0.02 & 0.80 & 0.16 & 4.60 & 99.84 \\
\hline P5 & 5.49 & 2.14 & 6.22 & 75.71 & 0.29 & 2.72 & 0.67 & 0.02 & 0.85 & 0.18 & 5.76 & 100.05 \\
\hline P6 & 5.12 & 3.58 & 4.91 & 67.74 & 0.22 & 1.65 & 6.74 & 0.01 & 0.76 & 0.14 & 9.26 & 100.12 \\
\hline P7 & 5.44 & 3.31 & 4.34 & 79.18 & 0.25 & 2.21 & 0.82 & 0.01 & 0.67 & 0.17 & 3.56 & 99.97 \\
\hline P8 & 5.19 & 3.42 & 3.99 & 59.44 & 0.34 & 1.53 & 11.86 & 0.01 & 0.65 & 0.14 & 13.29 & 99.85 \\
\hline P9 & 3.64 & 1.74 & 1.82 & 35.04 & 0.41 & 1.06 & 26.47 & 0.01 & 0.33 & 0.09 & 29.25 & 99.86 \\
\hline
\end{tabular}

\section{Results and discussion}

Table 2 shows the results obtained from the chemical analysis of all the size fractions used. It is seen that $\mathrm{Fe}_{2} \mathrm{O}_{3}$ is the most abundant constituent, varying between 55.14 and $75.92 \%$, while $\mathrm{SiO}_{2}$ has much lower content of about 5.31 to $11.68 \%$. The $\mathrm{NiO}$ content has
$0.67 \%$ in the coarser size fraction and increases with decreasing size fraction up to $1.88 \%$ in the finer one. The latter can be explained by the fact that the soft groundmass is richer in nickel than pisolites and after breakage the fines contain more nickel than the coarse fractions. 
Table 2. Chemical analysis of the size fraction samples

\begin{tabular}{|l|c|c|c|c|c|c|c|c|c|c|c|c|c|}
\hline $\begin{array}{c}\text { Size } \\
\text { fractions } \\
(\mathbf{m m})\end{array}$ & $\begin{array}{c}\text { Weight } \\
(\boldsymbol{\%})\end{array}$ & $\begin{array}{c}\mathbf{S i O}_{\mathbf{2}} \\
(\mathbf{\%})\end{array}$ & $\begin{array}{c}\mathbf{A l}_{\mathbf{2}} \mathbf{O}_{\mathbf{3}} \\
(\boldsymbol{\%})\end{array}$ & $\begin{array}{c}\mathbf{C r}_{\mathbf{2}} \mathbf{O}_{\mathbf{3}} \\
(\boldsymbol{\%})\end{array}$ & $\begin{array}{c}\mathbf{F e}_{\mathbf{2}} \mathbf{O}_{\mathbf{3}} \\
(\boldsymbol{\%})\end{array}$ & $\begin{array}{c}\mathbf{M n O} \\
(\boldsymbol{\%})\end{array}$ & $\begin{array}{c}\mathbf{M g O} \\
(\boldsymbol{\%})\end{array}$ & $\begin{array}{c}\mathbf{C a O} \\
(\%)\end{array}$ & $\begin{array}{c}\mathbf{K}_{2} \mathbf{O} \\
(\%)\end{array}$ & $\begin{array}{c}\mathbf{N i O} \\
(\%)\end{array}$ & $\begin{array}{c}\mathbf{C o O} \\
(\%)\end{array}$ & $\begin{array}{c}\mathbf{L O I} \\
(\%)\end{array}$ & $\begin{array}{c}\mathbf{S U M} \\
(\%)\end{array}$ \\
\hline$-8.00+4.00$ & 53.58 & 5.31 & 3.89 & 5.56 & 75.92 & 0.28 & 1.89 & 1.23 & 0.02 & 0.67 & 0.17 & 4.96 & 99.89 \\
\hline$-4.00+1.00$ & 28.51 & 5.70 & 2.17 & 5.14 & 74.82 & 0.29 & 1.93 & 2.48 & 0.02 & 0.74 & 0.16 & 6.55 & 100.00 \\
\hline$-1.00+0.250$ & 10.01 & 6.18 & 2.17 & 6.21 & 71.90 & 0.29 & 2.66 & 2.45 & 0.02 & 0.87 & 0.16 & 7.19 & 100.10 \\
\hline$-0.250+0.063$ & 4.14 & 7.08 & 3.94 & 7.45 & 66.33 & 0.33 & 2.52 & 2.52 & 0.01 & 1.06 & 0.17 & 8.34 & 99.76 \\
\hline-0.063 & 3.77 & 11.68 & 6.81 & 2.78 & 55.14 & 0.86 & 4.57 & 2.79 & 0.03 & 1.88 & 0.16 & 13.26 & 99.95 \\
\hline Total & 100 & 5.82 & 3.34 & 5.48 & 74.03 & 0.31 & 2.10 & 1.82 & 0.02 & 0.77 & 0.17 & 6.09 & 99.95 \\
\hline
\end{tabular}

\subsection{Gravimetric separation}

The results of the gravimetric separation of the size fractions $-8+4 \mathrm{~mm},-4+1 \mathrm{~mm}$,
$-1+0.250 \mathrm{~mm}$ and $-0.250+0.063 \mathrm{~mm}$ using tetrabromoethane as the heavy liquid are shown in Table 3.

Table 3. Results of gravimetric separation through heavy liquids

\begin{tabular}{|c|c|c|c|c|c|c|c|c|c|c|}
\hline & & \multicolumn{3}{|c|}{ Weights } & \multicolumn{3}{|c|}{ Chemical analysis $(\%)$} & \multicolumn{3}{|c|}{ Distribution (\%) } \\
\hline $\begin{array}{l}\text { Size fractions } \\
(\mathrm{mm})\end{array}$ & Product & $\begin{array}{c}\text { Weight } \\
\text { (g) }\end{array}$ & $\begin{array}{c}\text { Product } \\
\text { weight } \\
(\%)\end{array}$ & $\begin{array}{c}\text { Weight of } \\
\text { the initial } \\
(\%)\end{array}$ & $\mathrm{NiO}$ & $\mathrm{Fe}_{2} \mathrm{O}_{3}$ & $\mathrm{SiO}_{2}$ & $\mathrm{NiO}$ & $\mathrm{Fe}_{2} \mathrm{O}_{3}$ & $\mathrm{SiO}_{2}$ \\
\hline \multirow{3}{*}{$-8+4$} & Sink & 669.62 & 95.55 & 52.03 & 0.86 & 74.22 & 5.34 & 97.06 & 97.64 & 96.32 \\
\hline & Float & 31.19 & 4.45 & 2.42 & 0.56 & 38.46 & 4.38 & 2.94 & 2.36 & 3.68 \\
\hline & Total & 700.81 & 100 & 54.45 & 0.85 & 72.63 & 5.30 & 100 & 100 & 100 \\
\hline \multirow{3}{*}{$-4+1$} & Sink & 281.9 & 81.26 & 21.90 & 0.72 & 75.94 & 5.18 & 74.99 & 84.33 & 77.53 \\
\hline & Float & 65.02 & 18.74 & 5.05 & 1.05 & 61.20 & 6.51 & 25.01 & 15.67 & 22.47 \\
\hline & Total & 346.92 & 100 & 26.96 & 0.78 & 73.18 & 5.43 & 100 & 100 & 100 \\
\hline \multirow{3}{*}{$-1+0.250$} & Sink & 101.08 & 93.07 & 7.85 & 0.78 & 72.66 & 5.46 & 82.26 & 96.88 & 82.85 \\
\hline & Float & 7.53 & 6.93 & 0.59 & 2.27 & 31.46 & 15.18 & 17.74 & 3.12 & 17.15 \\
\hline & Total & 108.61 & 100 & 8.44 & 0.89 & 69.80 & 6.14 & 100 & 100 & 100 \\
\hline \multirow{3}{*}{$-0.250+0.063$} & Sink & 34.93 & 88.21 & 2.71 & 0.83 & 68.50 & 6.74 & 72.89 & 90.77 & 85.59 \\
\hline & Float & 4.67 & 11.79 & 0.36 & 2.30 & 52.09 & 8.49 & 27.11 & 9.23 & 14.41 \\
\hline & Total & 39.6 & 100 & 3.08 & 1.00 & 66.56 & 6.95 & 100 & 100 & 100 \\
\hline \multirow[t]{2}{*}{-0.063} & & 91.03 & 100 & 7.07 & 1.88 & 55.14 & 11.68 & 100 & 100 & 100 \\
\hline & Total & 1286.97 & & 100 & 0.43 & 71.11 & 23.17 & & & \\
\hline
\end{tabular}

The weight percentages, the chemical analysis and distributions (\%) of the $\mathrm{Fe}_{2} \mathrm{O}_{3}$, $\mathrm{SiO}_{2}$ and $\mathrm{NiO}$ are presented in this Table. From the results obtained the following remarks can be made:

- The weight percentages of the sink products are much higher compared to those of the floats for all the size fractions used. This is actually justified by the fact that the initial material is rich in $\mathrm{Fe}_{2} \mathrm{O}_{3}$ presence in the form of hematite and goethite.

- There are differences in the content of $\mathrm{NiO}$ between the sink products and the float ones. The $\mathrm{NiO}$ content of the floats is higher compared to that of the sinks with an exception in the coarsest fraction $-8+4 \mathrm{~mm}$. Furthermore, there is a tendency of increasing the $\mathrm{NiO}$ content with decreasing size fraction and obtaining the highest value of $2.30 \%$ in the size fraction $-0.250+0.063 \mathrm{~mm}$. However, the $\mathrm{NiO}$ constituent is by far distributed to the sink products for all the size fractions used. The groundmass, which is rich in nickel, is gradually replaced by ferrous solutions and this may be the reason that nickel is distributed to the sink products.

- There is an obvious difference in the content of $\mathrm{Fe}_{2} \mathrm{O}_{3}$ between the sink products and the float ones but it still 
remains almost the same with the initial size fraction. In addition, the largest amount of $\mathrm{Fe}_{2} \mathrm{O}_{3}$, which ranges from 84 to $98 \%$, goes to the sink products since the $\mathrm{Fe}_{2} \mathrm{O}_{3}$ distributions (\%) of all the size fractions used are much higher in the sinks compared to those in the floats.

- The $\mathrm{SiO}_{2}$ content of the float products is higher compared to that of the sinks with an exception in the coarsest fraction $-8+4$ $\mathrm{mm}$. Obviously, at this size range the hematite is not liberated and a part of groundmass consisting of chlorite is distributed to the sink products. The latter is also explained from the results obtained of the $\mathrm{SiO}_{2}$ distributions of the products. The largest amount of $\mathrm{SiO}_{2}$ is distributed to the sink products ranging from 77 to $96 \%$.

It should be noted that a high $\mathrm{NiO}$ content $(1.05 \%)$ has been also observed in the nickel lateritic ore of Nome (Albania) of the size fraction $-0.063 \mathrm{~mm}[5]$.

The coarser fractions $(-8+4 \mathrm{~mm}$ and $-4+1$ $\mathrm{mm})$ have higher than expected content of nickel due to the lack of the mineral liberation, but in finer size fractions $(-1+0.250 \mathrm{~mm}$ and $-0.250+0.063 \mathrm{~mm})$ the liberation becomes better giving a $\mathrm{NiO}$

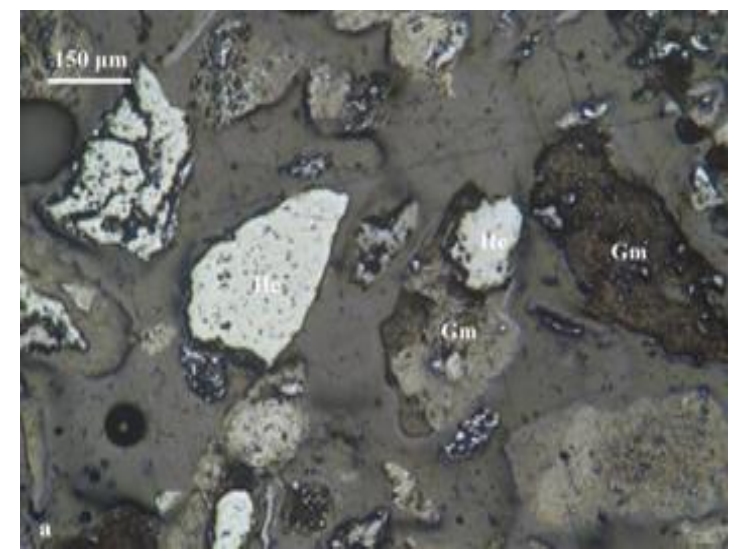

Figure 7. (a) Non-liberated grains of hematite (He) and groundmass $(\mathrm{Gm})$ (sink product, size fraction $-1+0.250 \mathrm{~mm}$ ), (b) Groundmass $(\mathrm{Gm})$ with inclusions of hematite (He) (float, size

fraction $-1+0.250 \mathrm{~mm})$. Reflected light, //Nicols

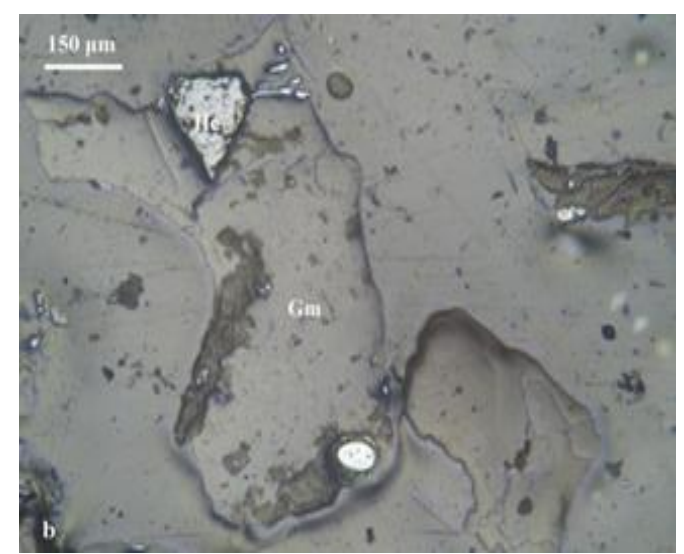

content up to $2.30 \%$. Nickel goes to the float products in all of the size fractions, with an exception for the size fraction $-8+4 \mathrm{~mm}$, where the sink product is richer in nickel content $(0.86 \%$ vs. $0.56 \% \mathrm{NiO})$, as seen in Table 3 and Figure 6.

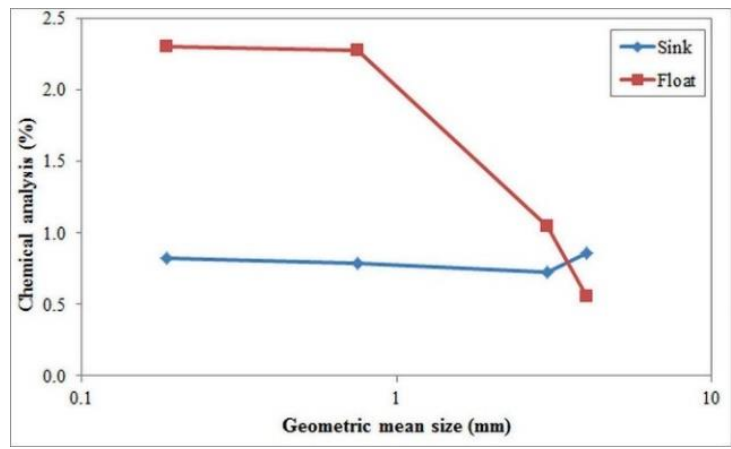

Figure 6. Chemical analysis of $\mathrm{NiO}$ versus mean size of the products through the gravimetric separation

The microscopic analysis of the polished sections provides useful information concerning minerals intergrowth. In the sink products non-liberated grains of chromite and hematite appear, as seen in Figure 7(a). Similar results are obtained from Figure 7(b) where inclusions of hematite are present in the groundmass. 
The sink products of both size fractions $-8+4 \mathrm{~mm}$ and $-4+1 \mathrm{~mm}$ were further treated through the heavy suspension liquid technique. Table 4 shows the weight percentages, the chemical analysis and distribution (\%) of the $\mathrm{Fe}_{2} \mathrm{O}_{3}, \mathrm{SiO}_{2}$ and $\mathrm{NiO}$.

Table 4. Results of gravimetric separation through the heavy suspension liquid technique

\begin{tabular}{|c|c|c|c|c|c|c|c|c|c|c|}
\hline & & \multicolumn{3}{|c|}{ Weights } & \multicolumn{3}{|c|}{ Chemical analysis (\%) } & \multicolumn{3}{|c|}{ Distribution (\%) } \\
\hline $\begin{array}{c}\text { Size } \\
\text { fractions } \\
(\mathbf{m m})\end{array}$ & Product & $\begin{array}{c}\text { Weight } \\
\text { (g) }\end{array}$ & $\begin{array}{c}\text { Fraction } \\
\text { weight } \\
(\%)\end{array}$ & $\begin{array}{c}\text { Weight on } \\
\text { the initial } \\
(\%)\end{array}$ & $\mathrm{NiO}$ & $\mathrm{Fe}_{2} \mathrm{O}_{3}$ & $\mathrm{SiO}_{2}$ & $\mathrm{NiO}$ & $\mathrm{Fe}_{2} \mathrm{O}_{3}$ & $\mathrm{SiO}_{2}$ \\
\hline \multirow{3}{*}{$-8+4$} & $\begin{array}{c}\text { Sink } \\
\left(+4 \mathrm{~g} / \mathrm{cm}^{3}\right)\end{array}$ & 329.83 & 49.26 & 25.63 & 0.65 & 77.56 & 4.82 & 37.52 & 51.47 & 44.44 \\
\hline & $\begin{array}{c}\text { Float } \\
\left(-4+2.96 \mathrm{~g} / \mathrm{cm}^{3}\right)\end{array}$ & 339.79 & 50.74 & 26.40 & 1.06 & 70.98 & 5.85 & 62.48 & 48.53 & 55.56 \\
\hline & $\begin{array}{c}\text { Initial } \\
\left(+2.96 \mathrm{~g} / \mathrm{cm}^{3}\right)\end{array}$ & 669.62 & 100 & 52.03 & 0.86 & 74.22 & 5.34 & 100 & 100 & 100 \\
\hline \multirow{3}{*}{$-4+1$} & $\begin{array}{c}\text { Sink } \\
\left(+4 \mathrm{~g} / \mathrm{cm}^{3}\right)\end{array}$ & 77.69 & 27.56 & 6.04 & 0.42 & 82.87 & 4.09 & 15.95 & 30.07 & 21.76 \\
\hline & $\begin{array}{c}\text { Float } \\
\left(-4+2.96 \mathrm{~g} / \mathrm{cm}^{3}\right)\end{array}$ & 204.21 & 72.44 & 15.86 & 0.84 & 73.31 & 5.60 & 84.05 & 69.93 & 78.24 \\
\hline & $\begin{array}{c}\text { Initial } \\
\left(-2.96 \mathrm{~g} / \mathrm{cm}^{3}\right)\end{array}$ & 281.9 & 100 & 21.9 & 0.72 & 75.94 & 5.18 & 100 & 100 & 100 \\
\hline
\end{tabular}

From the results obtained, the following remarks can be made:

- The NiO content increases in the float products, as seen in Figure 8, and obtains the highest value of $1.06 \%$ in the size fraction $-8+4 \mathrm{~mm}$. Furthermore, the $\mathrm{NiO}$ constituent is mainly distributed to the float products and reaches a value of about $84 \%$ in the size fraction $-4+1 \mathrm{~mm}$ (Figure 9).

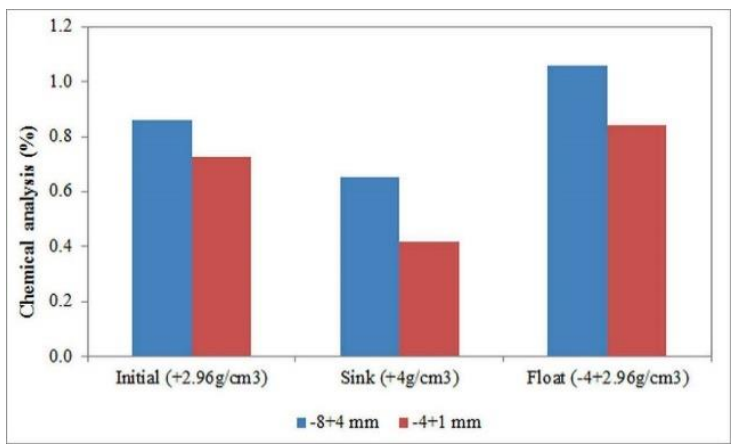

Figure 8. Chemical analysis of $\mathrm{NiO}$ in each size fraction of the products obtained from the gravimetric separation

- There is a little difference in the content of $\mathrm{Fe}_{2} \mathrm{O}_{3}$ between the sink products and the float ones. The greatest difference was found in the size fraction $-4+1 \mathrm{~mm}$ and amounts to about $83 \%$ and $73 \%$ in the sinks and floats, respectively. However, at this size fraction the $\mathrm{Fe}_{2} \mathrm{O}_{3}$ constituent is mainly distributed to the float products.

- The $\mathrm{SiO}_{2}$ content in the float products is a little higher compared to that in the sink ones. The same trend was found regarding the $\mathrm{SiO}_{2}$ distribution $(\%)$.

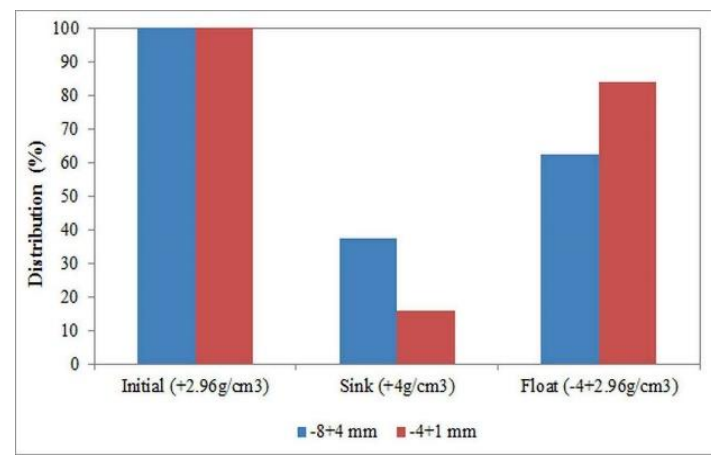

Figure 9. Distribution of $\mathrm{NiO}$ in each size fraction of the products obtained from the gravimetric separation

\subsection{Magnetic Separation}

Table 5 presents the results through magnetic separation of all the size fractions used. 
Table 5. Results of magnetic separation

\begin{tabular}{|c|c|c|c|c|c|c|c|c|c|c|c|}
\hline & & & \multicolumn{3}{|c|}{ Weights } & \multicolumn{3}{|c|}{ Chemical analysis $(\%)$} & \multicolumn{3}{|c|}{ Distribution (\%) } \\
\hline $\begin{array}{l}\text { Size fractions } \\
(\mathbf{m m})\end{array}$ & $\begin{array}{l}\text { Separation } \\
\text { Parameters }\end{array}$ & Product & $\begin{array}{c}\text { Weight } \\
\text { (g) }\end{array}$ & $\begin{array}{c}\text { Fraction } \\
\text { weight } \\
(\%)\end{array}$ & $\begin{array}{c}\text { Weight on } \\
\text { the initial } \\
(\%)\end{array}$ & $\mathrm{NiO}$ & $\mathrm{Fe}_{2} \mathrm{O}_{3}$ & $\mathrm{SiO}_{2}$ & $\mathrm{NiO}$ & $\mathrm{Fe}_{2} \mathrm{O}_{3}$ & $\mathrm{SiO}_{2}$ \\
\hline \multirow{5}{*}{$-8+4$} & $180 \mathrm{rpm}$ & Non-Magnetic 1 & 14.8 & 2.58 & 1.29 & 0.46 & 68.63 & 4.35 & 1.49 & 2.46 & 2.23 \\
\hline & $220 \mathrm{rpm}$ & Non-Magnetic 2 & 48.2 & 8.41 & 4.19 & 0.72 & 76.40 & 2.13 & 7.58 & 8.92 & 3.57 \\
\hline & $260 \mathrm{rpm}$ & Non-Magnetic 3 & 43.5 & 7.59 & 3.79 & 0.70 & 72.02 & 4.86 & 6.73 & 7.59 & 7.34 \\
\hline & $260 \mathrm{rpm}$ & Magnetic & 466.6 & 81.42 & 40.60 & 0.82 & 71.71 & 5.36 & 84.20 & 81.04 & 86.85 \\
\hline & & Total & 573.1 & 100 & 49.87 & 0.80 & 72.05 & 5.02 & 100 & 100 & 100 \\
\hline \multirow{5}{*}{$-4+1$} & $180 \mathrm{rpm}$ & Non-Magnetic 1 & 7.5 & 2.30 & 0.65 & 0.77 & 68.54 & 5.66 & 2.10 & 2.18 & 2.32 \\
\hline & $220 \mathrm{rpm}$ & Non-Magnetic 2 & 11.8 & 3.62 & 1.03 & 0.57 & 71.84 & 4.93 & 2.43 & 3.60 & 3.17 \\
\hline & $260 \mathrm{rpm}$ & Non-Magnetic 3 & 24.7 & 7.59 & 2.15 & 0.64 & 73.43 & 5.14 & 5.71 & 7.70 & 6.92 \\
\hline & $260 \mathrm{rpm}$ & Magnetic & 281.6 & 86.49 & 24.50 & 0.88 & 72.35 & 5.70 & 89.76 & 86.52 & 87.59 \\
\hline & & Total & 325.6 & 100 & 28.33 & 0.85 & 72.32 & 5.63 & 100 & 100 & 100 \\
\hline \multirow{5}{*}{$-1+0.250$} & $180 \mathrm{rpm}$ & Non-Magnetic 1 & 17.8 & 15.51 & 1.55 & 0.51 & 71.92 & 5.18 & 9.10 & 15.82 & 13.06 \\
\hline & $220 \mathrm{rpm}$ & Non-Magnetic 2 & 10.7 & 9.32 & 0.93 & 0.96 & 69.44 & 6.71 & 10.30 & 9.18 & 10.18 \\
\hline & $260 \mathrm{rpm}$ & Non-Magnetic 3 & 10.8 & 9.41 & 0.94 & 0.79 & 69.10 & 5.90 & 8.58 & 9.22 & 9.03 \\
\hline & $260 \mathrm{rpm}$ & Magnetic & 75.5 & 65.77 & 6.57 & 0.95 & 70.51 & 6.33 & 72.02 & 65.78 & 67.74 \\
\hline & & Total & 114.8 & 100 & 9.99 & 0.87 & 70.50 & 6.15 & 100 & 100 & 100 \\
\hline \multirow{5}{*}{$-0.250+0.063$} & $180 \mathrm{rpm}$ & Non-Magnetic 1 & 6 & 13.42 & 0.52 & 1.11 & 55.88 & 9.11 & 12.49 & 11.30 & 15.44 \\
\hline & $220 \mathrm{rpm}$ & Non-Magnetic 2 & 5.6 & 12.53 & 0.49 & 1.33 & 62.12 & 9.59 & 14.02 & 11.72 & 15.17 \\
\hline & $260 \mathrm{rpm}$ & Non-Magnetic 3 & 3.8 & 8.50 & 0.33 & 1.24 & 63.94 & 9.55 & 8.88 & 8.19 & 10.25 \\
\hline & $260 \mathrm{rpm}$ & Magnetic & 29.3 & 65.55 & 2.55 & 1.18 & 69.66 & 7.14 & 64.61 & 68.79 & 59.13 \\
\hline & & Total & 44.7 & 100 & 1.34 & 1.19 & 66.38 & 7.92 & 100 & 100 & 100 \\
\hline-0.063 & & & 91.03 & 100 & 7.92 & 1.88 & 55.14 & 11.68 & 100 & 100 & 100 \\
\hline Total & & & 1149.23 & & 97.45 & 0.92 & 70.41 & 5.95 & & & \\
\hline
\end{tabular}

As already mentioned, one magnetic product and three non-magnetics were obtained through the whole process. In this table the weight percentages, the chemical analysis and distribution (\%) of the $\mathrm{Fe}_{2} \mathrm{O}_{3}$, $\mathrm{SiO}_{2}$ and $\mathrm{NiO}$ are presented. From the results of the magnetic separation, the following remarks can be made:

- The weight percentages of the magnetic products are higher compared to those of the non-magnetics for all the size fractions used. The latter is actually justified by the fact that the initial material is rich in $\mathrm{Fe}_{2} \mathrm{O}_{3}$ present in the form of hematite and goethite.

- The NiO content of the magnetic products is higher compared to that of the nonmagnetic ones in the coarser fractions $(-8+4 \mathrm{~mm}$ and $-4+1 \mathrm{~mm})$ while in finer fractions $(-1+0.250 \mathrm{~mm}$ and $-0.250+0.063 \mathrm{~mm}$ ) the highest content is observed in the non-magnetic 2 product (Figure 10). Nevertheless, there is a tendency of increasing the $\mathrm{NiO}$ content with decreasing size fraction and obtaining the highest value of $1.33 \%$ in the finer size fraction used. However, the $\mathrm{NiO}$ constituent is by far distributed to the magnetic products for all the size fractions used and this can be justified by the fact that the groundmass which is rich in nickel is gradually replaced by ferrous solutions.

- An obvious difference is not detected in the content of $\mathrm{Fe}_{2} \mathrm{O}_{3}$ between the magnetic products and the non-magnetic ones and it still remains almost the same with the initial size fraction. However, the largest amount of $\mathrm{Fe}_{2} \mathrm{O}_{3}$, which ranges from 66 to $87 \%$, is distributed to the magnetic products.

- The $\mathrm{SiO}_{2}$ content of the non-magnetic products is generally higher compared to that of the magnetics only in the finer size fractions. Furthermore, there is a tendency of increasing the $\mathrm{SiO}_{2}$ content with decreasing size fraction and obtains the highest value of about $9.59 \%$ in the size fraction $-0.250+0.063 \mathrm{~mm}$. However, the largest amount of $\mathrm{SiO}_{2}$ is distributed to the magnetic products ranging from 59 to $88 \%$. 
The microscopic analysis of the products obtained through magnetic separation is shown in Figure 11. Figure 11(a) shows the groundmass and the non-liberated grains of hematite of the non-magnetic product 1 in the size fraction $-0.250+0.063 \mathrm{~mm}$. On the other hand, figure 11(b) shows the liberated grains of hematite in the magnetic product of the same size fraction $(-0.250+0.063 \mathrm{~mm})$.

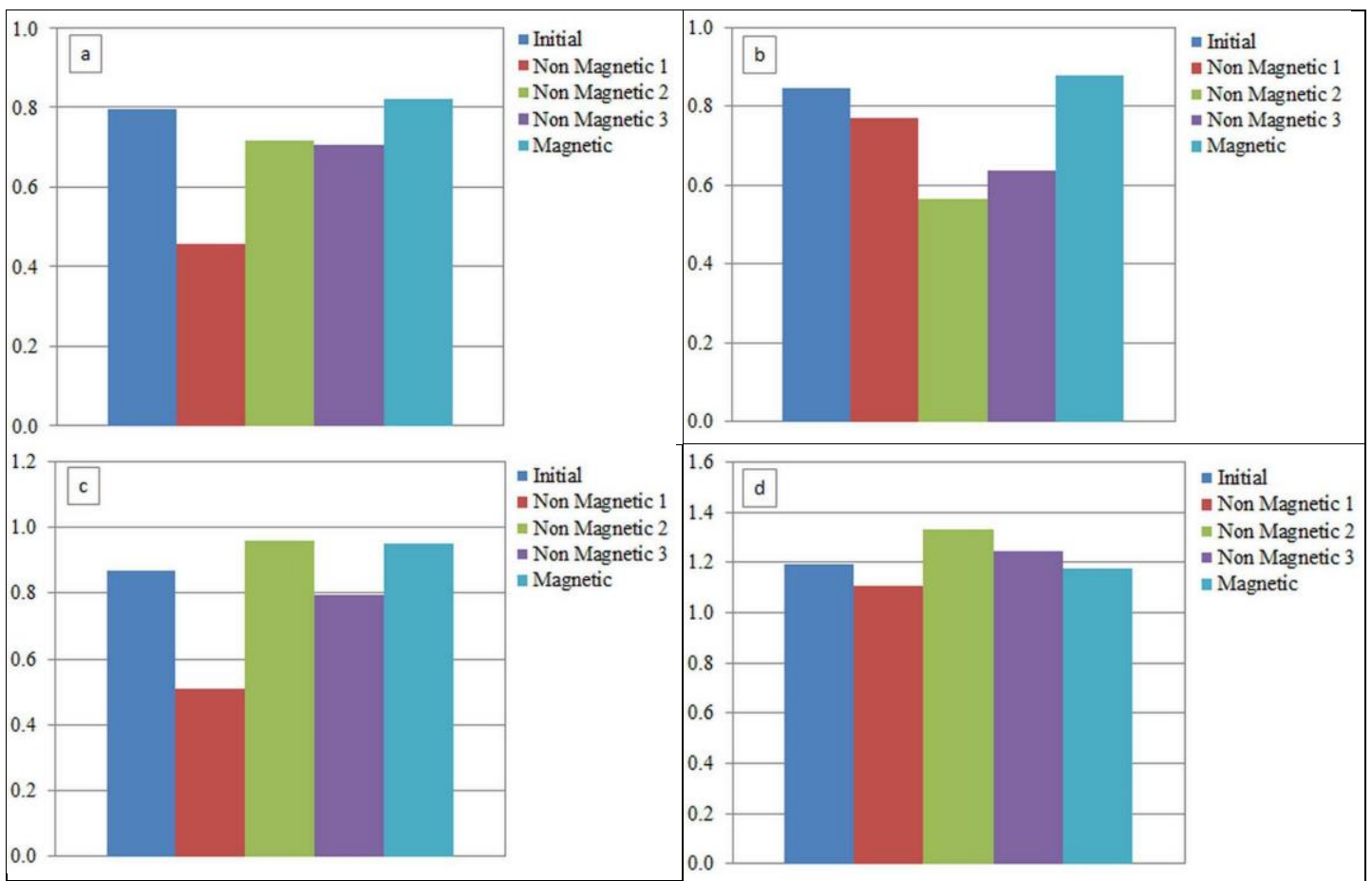

Figure 10. Chemical analysis of $\mathrm{NiO}$ of the products through magnetic separation in the size fractions (a) $-8+4 \mathrm{~mm}$, (b) $-4+1 \mathrm{~mm}$, (c) $-1+0.250 \mathrm{~mm}$, (d) $-0.250+0.063 \mathrm{~mm}$
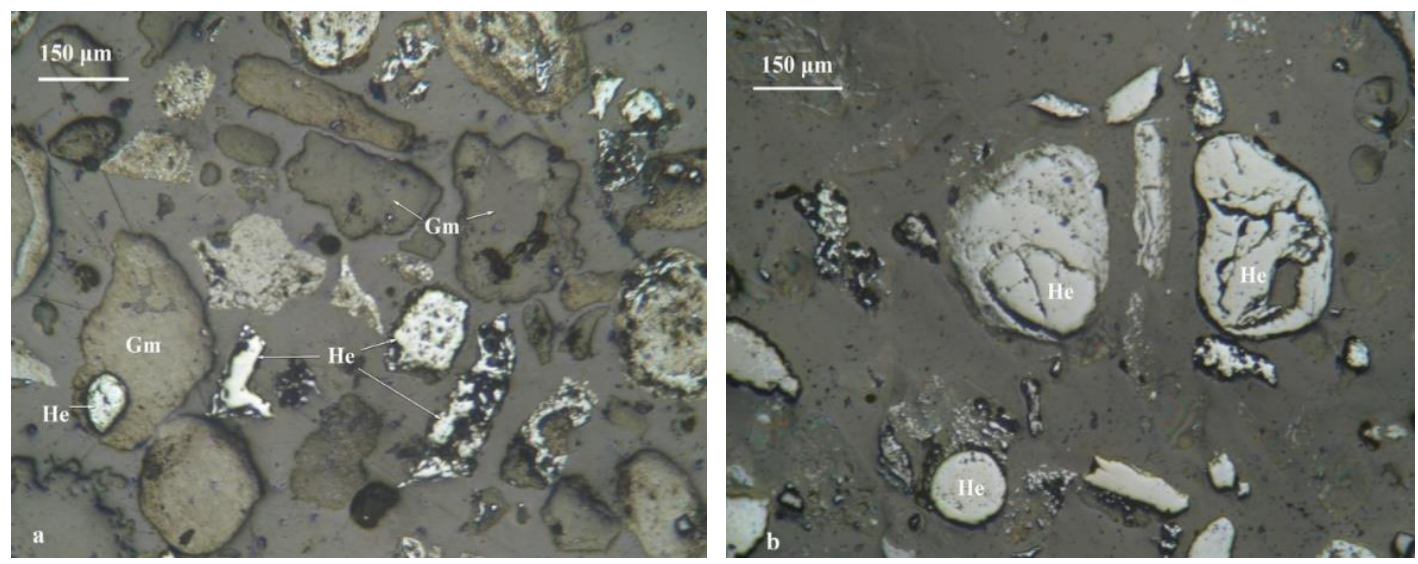

Figure 11. (a) Groundmass $(\mathrm{Gm})$ and non-liberated grains of hematite $(\mathrm{He})$ (Non-Magnetic product 1, size fraction $(-0.250+0.063 \mathrm{~mm})$, (b) Liberated grains of hematite (He) (Magnetic product, size fraction $(-0.250+0.063 \mathrm{~mm})$ Reflected light, //Nicols 


\section{Discussion and Conclusions}

The iron nickel ore of Hudenisht in Pogradec area developed in the form of layers over altered ophiolites. Above the ophiolites, there are the following layers: a clay iron nickel layer, two pisolitic layers, a compact iron-nickel layer with few pisolites, three pisolitic layers and finally in the top there is a layer which transits to a limestone roof (cup rock). The main mineral phases of the ore are hematite, goethite and chromite, with chlorite (clinochlore, nimite), lizardite, calcite and spinel as minor phases. Ferrous solutions of epigenetic origin replace the groundmass between the grains of the ore in the form of goethite. Hematite is found mainly in the form of pisoids, ooids, peloids and complex spheroids. There is also observed hematite, in minor constitute, as product of the dehydration of the preexisting goethite material. The grains of chromite appear either liberated in the ore or as inclusions in the groundmass. The main nickel-bearing phace is nickel chlorite (nimite) which exists in the groundmass of the ore.

The gravimetric separation through heavy liquids showed that the largest amount of each size fraction used is distributed to the sink products. This can be explained by the fact that the initial material is rich in heavy minerals, namely hematite and goethite. In addition, the groundmass, which is rich in nickel, is gradually replaced by ferrous solutions. As a result, nickel is by far distributed to the sinks. On the other hand, the nickel content of the floats is higher compared to that of the sinks with an exception in the coarsest fraction $-8+4 \mathrm{~mm}$. As it can be seen microscopically this fraction contains a lot of non-liberated grains of hematite and chromite and therefore a large amount of the groundmass which is rich in nickel goes to the sinks. It is also clearly observed that nickel content increases with decreasing size fraction and obtains the highest value of $2.30 \% \mathrm{NiO}$ (upgrade 130\%) in the size fraction $0.250+0.063 \mathrm{~mm}$. In general, the $\mathrm{SiO}_{2}$ content of the float products is higher compared to that of the sinks with an exception in the coarsest fraction $-8+4 \mathrm{~mm}$. At this size fraction the grains of hematite are nonliberated and some groundmass consisting of chlorite is distributed to the sink products. $\mathrm{Fe}_{2} \mathrm{O}_{3}$ reports into the sink products and this can be explained by the fact that the material is rich in iron present in the form of hematite and goethite. The gravimetric separation through the heavy suspension liquid technique showed that the coarse fractions can be further treated and the highest content of $1.06 \% \mathrm{NiO}$ (upgrade $23.3 \%$ ) is obtained in the float product of the size fraction $-8+4 \mathrm{~mm}$. The nickel distribution of this size fraction is also high $(62.5 \%)$.

The magnetic separation showed that the largest amount of the size fractions used is distributed to the magnetic products. This result is indeed explained by the fact that the initial material is rich in iron present in the form of hematite and goethite. The iron-rich material as well as the non-liberated minerals has the effect that nickel is predominantly distributed to the magnetic products. The information of minerals intergrowth provided by the microscopic analysis may also explain the fact that the nickel content of the magnetic products is higher compared to that of the non-magnetic ones in the coarser fractions. The minerals are liberated to a higher degree in finer sizes and as a result at these fractions nickel achieves higher content values in the non-magnetic products. Overall, the highest content of $1.33 \% \mathrm{NiO}$ (upgrade $11.8 \%$ ) is detected in the non-magnetic 2 product of the $-0.250+0.063 \mathrm{~mm}$ fraction. It is also observed that at this stage the nickel distribution is low $(14.02 \%)$. In addition, the largest amount of $\mathrm{SiO}_{2}$, ranging from 59 to $88 \%$, is distributed to the magnetic products which indicates that 
the magnetic separation is not adequate for upgrading the ore. The latter is supported by the fact that $\mathrm{Fe}_{2} \mathrm{O}_{3}$, with a range of 66 to $87 \%$, is mainly distributed to the magnetic products. It should also be mentioned that the finer size fraction $-0.063 \mathrm{~mm}$ which was not subjected to any beneficiation process is rich in nickel $(1.88 \% \mathrm{NiO})$ indicating that the ore should be upgraded only by removing the coarse fraction from the feed. The soft groundmass is richer in nickel than the grains of hematite or chromite and after breakage the fine fraction contains more nickel than the coarse fractions that have been upgraded. This is by far the most common pre-concentration process used in hydrometallurgical treatment of $\mathrm{Ni}$ laterites.

\section{References}

[1] Sakaroglou, M., Anastassakis, G. (2017) Nickel recovery from electric arc furnace slag by magnetic separation. Journal of Mining and Metallurgy, 53 A (1), 3-15.

[2] Rice, N.M. (2016) A hydrochloric acid process for nickeliferous laterites. Minerals Engineering, 88, 28-52.

[3] Kuck, P. (2005) Nickel. U.S.Geological Survey, 2006 Minerals Yearbook, Mineral Commodity Summaries.

[4] Apostolikas, A. (2009) Nickel deposits. Efyra Publications, Kastoria (in Greek).

[5] Katzagiannakis, N., Alevizos, G., Stamboliadis, E., Stratakis, A., Petrakis, E. (2014) Mineralogical investigation and washability treatment of the nickeliferous lateritic deposit of Nome (Albania). Geomaterials, 4, 105-115.

[6] Nosrati, A., Quast, K., Xu, D., Skinner, W., Robinson, D.J., Addai-Mensah, J. (2014) Agglomeration and column leaching behaviour of nickel laterite ores: effect of ore mineralogy and particle size distribution. Hydrometallurgy, 146, 29-39.

[7] Zhou, Y. Wei, B. Li, H. Wang, B. Ma, C. Wang, X. Luo, (2017) Mineralogical characterization and design of a treatment process for Yunnan nickel laterite ore, China. International Journal of Mineral Processing, Vol. 159, 51-59.

[8] Alevizos, G., Apostolikas, A., Stratakis, A. (2015) Mineralogical and orepetrographic investigation of the Nickeliferous Lateritic Deposit of Hudenisht in Pogradec area (Albania). In: Annual Meeting of DGGV-DMG, GeoBerlin, 4-7 Oct. 2015, 65-66.

[9] Valeton, I, Biermann, M., Reche, R. Rosenberg, F. (1987) Genesis of nickel laterites and bauxites in Greece during the Jurassic and Cretaceous, and their relation to ultrabasic parent rocks. Ore Geology Reviews, 2(4), 359-404.

[10] Agatzini-Leonardou, S., Zafiratos, I.G. (2004) Beneficiation of a Greek serpentinic nickeliferous ore part II. Sulphuric acid heap and agitation leaching. Hydrometallurgy, 74, 267-275.

[11] Norgate, T., Jahanshahi, S. (2010) Low grade ores - smelt, leach or concentrate?. Minerals Engineering, 23, 65-73.

[12] Quast, K., Connor, J.N., Skinner, W., Robinson, D.J., Addai-Mensah, J. (2015) Preconcentration strategies in the processing of nickel laterite ores Part 1: Literature review, Minerals Engineering, 79, 261-268.

[13] Quast, K., Xu, D., Skinner, W., Nosrati, A., Hilder, T., Robinson, D.J., AddaiMensah, J. (2013) Column leaching of nickel laterite agglomerates: effect of feed size. Hydrometallurgy, 134-135, 144-149.

[14] Frasheri, A., Bushati, S., Bare, V. (2009) Geophysical outlook on structure of the Albanides. Journal of the Balkan Geophysical Society, 12 (1), 9-30.

[15] Gawlick, H.-J., Frisch, W., Hoxha, L., Dumitrica, P., Krystyn, L., Lein, R., Missoni, S., Schlagintweit, F. (2008) Mirdita Zone Ophiolites and Associated 
Sediments in Albania Reveal Neotethys Ocean Origin. International Journal of Earth Sciences (Geol.Rundsch), 97, 865881.

[16] Alevizos, G., Apostolikas, A., Repouskou, E. (2011) Mineralogical-petrographic and geochemical investigation of the Nickeliferous Lateritic Deposit of Nome
(N.E. Albania), Mineral Wealth, 161, 721 (in Greek).

[17] Alevizos, G., Repouskou, E. (2011) Ore microscopy and microanalysis of the Nickeliferous Iron Ores from Komnina Vermion Area (N.W. Greece). Geomaterials, 1, 44-48. 


\title{
MINEROLOŠKA ISPITIVANJA I PRELIMINARNA ISTRAŽIVANJA OPLEMENJIVANJA NIKLONOSNO GVOŽĐEVITE LATERITSKE RUDE IZ LEŽIŠTA HUDENISHT
}

\author{
G. Alevizos ${ }^{1}$, A. Stratakis ${ }^{1 \#}$, E. Petrakis ${ }^{1}$, R. Tselempis ${ }^{1}$, A. Apostolikas ${ }^{2}$ \\ ${ }^{1}$ Technical University of Crete, School of Mineral Resources Engineering, Chania, Greece \\ ${ }^{2}$ Larco GMMSA, Athens, Greece
}

(Primljen: 14. Jun 2018.; Prihvaćen: 28. Septembar 2018.)

\begin{abstract}
Izvod
Ruda gvožđa sa sadržajem nikla iz ležišta Hudenisht nalazi se u oblasti grada Pogradec u Albaniji. Pojavljuje se $u$ slojevima iznad izmenjenog ofiolita i prekrivena je krečnjakom iz perioda kasne krede. Za ispitivanje rude korišćene su rentgenska difrakcija, rudna mikroskopija i SEM analiza, i došlo se do zaključka da glavne mineralne faze čine hematit, getit $i$ hromit, a da je prisutan i manji sadržaj hlorita (klinohlor, nimit), lizardita, kalcita $i$ magnezijum aluminata. Osnovna faza koja sadrži nikl je nimit, koji se uglavnom nalazi u stenskoj masi rude. Hemijska XRF analiza pokazala je da je to siromašna ruda nikla $\left(0,8 \% \mathrm{NiO}\right.$ ) sa najvećim sadržajem $\mathrm{Fe}_{2} \mathrm{O}_{3}(74 \%)$. Primenom fizičkih metoda koncentracije, odnosno gravitacijskom i magnetnom separacijom izvršena su istraživanja valorizacije korisnih komponenata. Dobijeni uzorci su homogenizovani, zatim izdrobljeni do krupnoće $100 \%-8 \mathrm{~mm}$. Mokrim postupkom prosejavanja dobijene su četiri klase krupnoće: $-8+4 \mathrm{~mm},-4+1 \mathrm{~mm},-1+0,250 \mathrm{~mm} i$ $-0,250+0,063 \mathrm{~mm}$. Na svakoj klasa izvršena su predviđena ispitivanja i hemijska XRF analiza. Dobijeni rezultati iz oba procesa su pokazali da se bolji rezultati ostvaruju primenom procesa gravitacijske koncentracije. Može se zaključiti da su proizvodi sa većim sadržajem nikla dobijeni iz finijih klasa.
\end{abstract}

Ključne reči: niklonosno gvožđevita lateritska ruda; postupak oplemenjivanja; magnetna separacija; gravitacijska separacija; rudna mikroskopija; Hudenisht.

\footnotetext{
${ }^{\#}$ Kontakt adresa autora: astratak@mred.tuc.gr
}

doi: 10.5937/JMMA1801035A 